\title{
Synthesis, structure, and cation complexation of a novel crown ether porphyrin
}

\author{
Yen-Chun Liu ${ }^{a}$, Ming-Cheng Kuo ${ }^{\mathrm{a}}$, Cheng-Wei Lee ${ }^{\mathrm{a}}$, You-Ren Liang ${ }^{\mathrm{a}}$, \\ Gene-Hsiang Lee ${ }^{\mathrm{b}}$, Shie-Ming Peng ${ }^{\mathrm{b}}$, Chen-Yu Yeh ${ }^{\mathrm{a}, *}$ \\ a Department of Chemistry, National Chung Hsing University, Taichung 402, Taiwan \\ ${ }^{\mathrm{b}}$ Department of Chemistry, National Taiwan University, Taipei 106, Taiwan
}

\section{A R T I C L E I N F O}

\section{Article history:}

Received 30 August 2008

Revised 1 October 2008

Accepted 3 October 2008

Available online 7 October 2008

\section{Keywords:}

Complexation

Crown ether

Dimerization

Porphyrin

\section{A B S T R A C T}

A new porphyrin appended with four crown ether units at meso-positions via an acetylene bridge was synthesized and structurally characterized, and its complexation with a variety of metal and diammonium cations was investigated.

(c) 2008 Elsevier Ltd. All rights reserved.
Much effort has been devoted to the development of supramolecular architectures of porphyrin derivatives owing to their importance as model compounds to mimic biological processes and their applications in electronic and optical devices. ${ }^{1-4}$ In order to construct porphyrin supramolecules with well-defined geometry and orientation, numerous synthetic approaches have been developed. These approaches include covalent synthesis, ${ }^{5,6}$ and self-assembly by metal-coordination, ${ }^{7-11} \pi-\pi$ interaction, ${ }^{12}$ or hydrogen bonding. ${ }^{13-16}$ Among numerous means for constructing supramolecular architectures, the use of cation complexation of crown ether units appended to the porphyrin represents a remarkable approach since the size and atoms of the crown ether, and the linker between the porphyrin and crown ether can be changed. ${ }^{17}$ Since the first example of crown ether-appended porphyrins reported by Thanabal and Krishnan, ${ }^{18}$ a number of porphyrins bearing crown ether moieties have been synthesized, and the complexation of the crown ether units with a variety of cations to form porphyrin dimers or donor-acceptor dyads has been studied. ${ }^{19-24}$

We report here the synthesis and cation-induced dimerization of zinc 5,10,15,20-tetrakis[(benzo-18-crown-6)-4'-ylethynyl]porphyrin (1), in which the crown ether and porphyrin ring are bridged by an ethynyl linker as shown in Figure 1. The crown ether units in $\mathbf{1}$ are more flexible for rotation than those in the porphyrin system with benzo-crown ethers appended directly at the mesopositions such as zinc 5,10,15,20-tetrakis[(benzo-18-crown-6)-4'-

\footnotetext{
* Corresponding author. Tel.: +886 42285 2264; fax: +886 22862547.

E-mail address: cyyeh@dragon.nchu.edu.tw (C.-Y. Yeh).
}

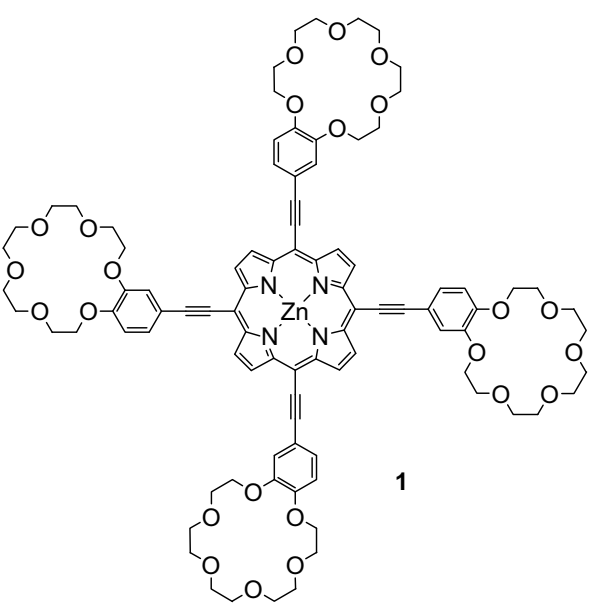

Figure 1. The structure of porphyrin 1 .

yl]porphyrin (2) ${ }^{18}$ and zinc 5,10,15,20-tetrakis[(benzo-15-crown5)-4'-yl]porphyrin (3). ${ }^{20}$ This makes porphyrin 1 feasible to form its dimer by complexing with a variety of cations.

We recently reported a simple synthetic route to tetrakis(arylethynyl)porphyrins using Sonogashira coupling reaction. ${ }^{25}$ The synthesis of the crown ether appended porphyrin 1 can be achieved by coupling of tetraethynylporphyrin $\mathbf{4}$ to iodide $\mathbf{5}$ under similar conditions (Scheme 1 ). Porphyrin 1 gave satisfactory spectroscopic data. 


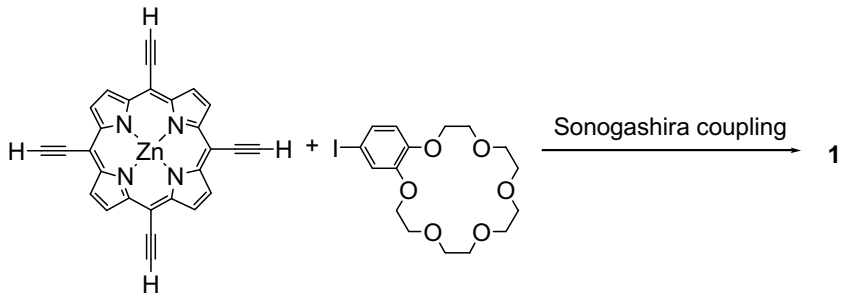

Scheme 1. The synthetic route for porphyrin 1.

The crystal structure of $\mathbf{1}$ is shown in Figure $2 .{ }^{26}$ The porphyrin macrocycle adopts an essentially planar arrangement and one of the crown ether units is disordered. The central zinc atom is bound to an axial methanol molecule and is pulled out of the porphyrin mean plane by $0.248 \AA$. The $\mathrm{Zn}-\mathrm{O}$ distance is $2.160 \AA$ and the average $\mathrm{Zn}-\mathrm{N}$ distance is $2.062 \AA$. The distances of $\mathrm{C} \equiv \mathrm{C}$ bonds fall in the normal range $1.189-1.198 \AA$, indicating no cumulenic character in the molecule. The dihedral angles between the acetylenebonded phenyl rings and the porphyrin mean plane are $2.04^{\circ}$, $5.85^{\circ}, 28.62^{\circ}$, and $41.81^{\circ}$, respectively. It is noteworthy that porphyrin 1 forms a dimeric structure in the solid state. As shown in Figure $2 \mathrm{~b}$, the axial methanol molecule is hydrogen bonded to the meta oxygen atom of the phenyl ring of the other porphyrin with an $\mathrm{O}-\mathrm{O}$ distance of $2.890 \AA$. The distance between the center
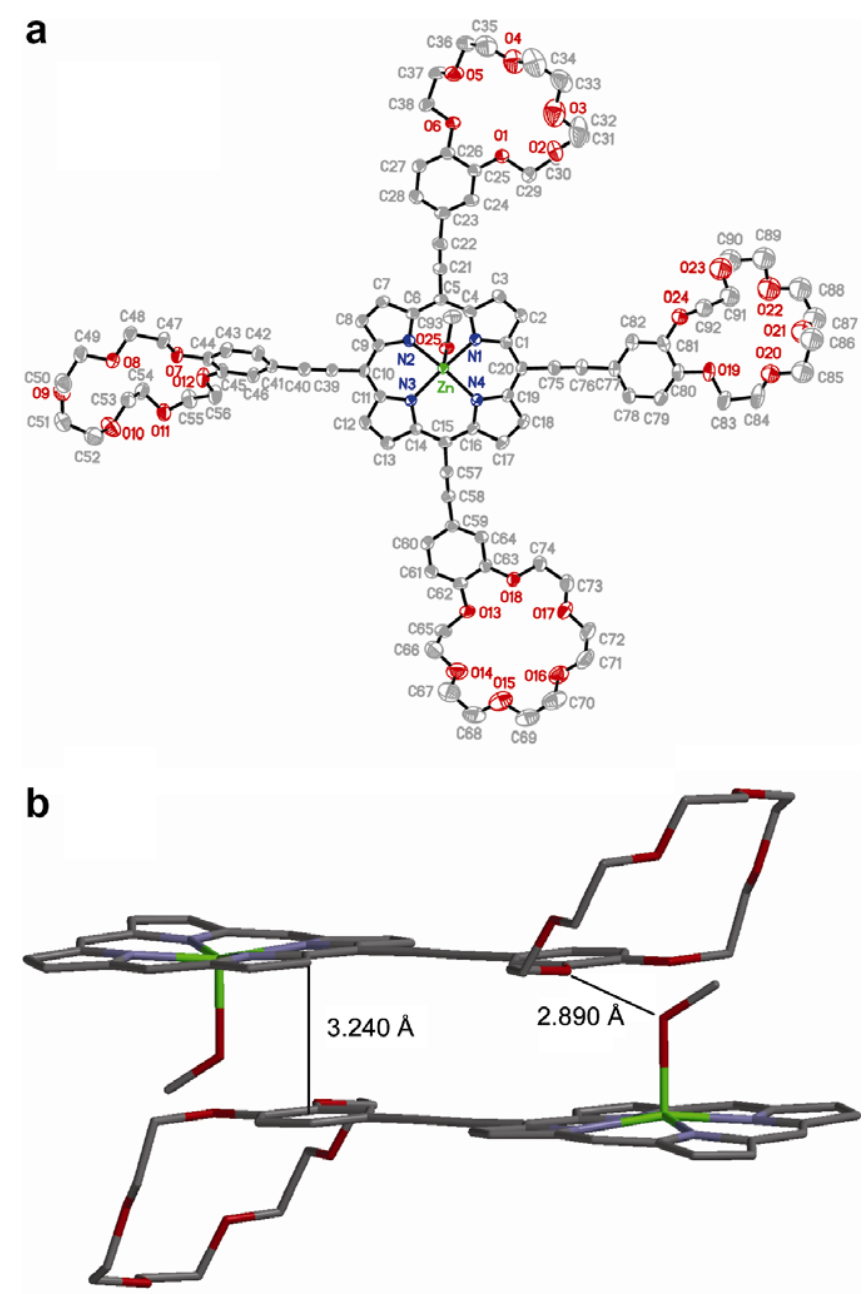

Figure 2. Crystal structure of $\mathbf{1}$ (hydrogen atoms omitted for clarity). The thermal ellipsoids were drawn at 50\% probability level: (a) molecular structure; (b) dimeric structure (six substituents at meso-positions omitted for clarity). of the phenyl ring and the porphyrin mean plane is $3.240 \AA$, suggesting strong $\pi-\pi$ interaction.

The complexation of porphyrin $\mathbf{1}$ with various cations was investigated by absorption titrations. Additions of $\mathrm{Li}^{+}, \mathrm{Na}^{+}, \mathrm{K}^{+}$, $\mathrm{Ca}^{2+}$, and $\mathrm{Mg}^{2+}$ ions to a solution of porphyrin 1 in $\mathrm{CH}_{2} \mathrm{Cl}_{2} / \mathrm{MeOH}$ (10:1) did not produce perceptible spectral changes. Previous studies showed that benzo-18-crown-6 is able to form $1: 1$ complex with a variety of metal ions such as $\mathrm{Li}^{+}, \mathrm{Na}^{+}$, and $\mathrm{K}^{+}$. ${ }^{27}$ The nearly unchanged spectra in the presence of these metal ions can be ascribed to the long distance between the crown ether units and the porphyrin ring. When $\mathrm{Cs}^{+}$ion was added to the solution of porphyrin 1, dramatic spectral changes were observed. Figure 3 shows the spectral changes of $\mathbf{1}$ upon addition of $0-2$ equiv of $\mathrm{Cs}^{+}$. The Soret band is blue shifted from 484 to $465 \mathrm{~nm}$ while the Q bands are slightly red shifted with lowered intensity. Several clear isosbestic points were observed in the course of titration, characteristic of an equillibrium between two states. Further addition of $\mathrm{Cs}^{+}$ion up to 100 equiv did not result in significant spectral changes. This result demonstrates that the $\mathbf{1 - C s}{ }^{+}$complex is highly stable even in the presence of excess $\mathrm{Cs}^{+}$ion. The high stability of the 1-Cs ${ }^{+}$complex is further verified by the fact that no perceptible spectral changes were observed, when excess $\mathrm{K}^{+}, \mathrm{Na}^{+}$, or $\mathrm{Li}^{+}$was added to the solution of $\mathbf{1}$ with 2 equiv of $\mathrm{Cs}^{+}$. The stoichiometry of the 1$\mathrm{Cs}^{+}$complex was confirmed by Job's plot. As shown in the inset of Fig. 3a, the maximum was observed at 0.34 , indicating the formation of a $2: 4\left(\mathbf{1}: \mathrm{Cs}^{+}\right)$complex. The stability constant for the formation of $\left(\mathbf{1}_{2} \mathrm{Cs}_{4}\right)^{4+}$ is calculated to be $3.2 \times 10^{30} \mathrm{M}^{-5}$ (SPECFIT software program), ${ }^{28}$ about $10^{20}$ larger than that for $\mathrm{Cs}^{+}$-complexing with a phthalocyanine analogue appending with four 18crown-6 ether moieties. ${ }^{29}$

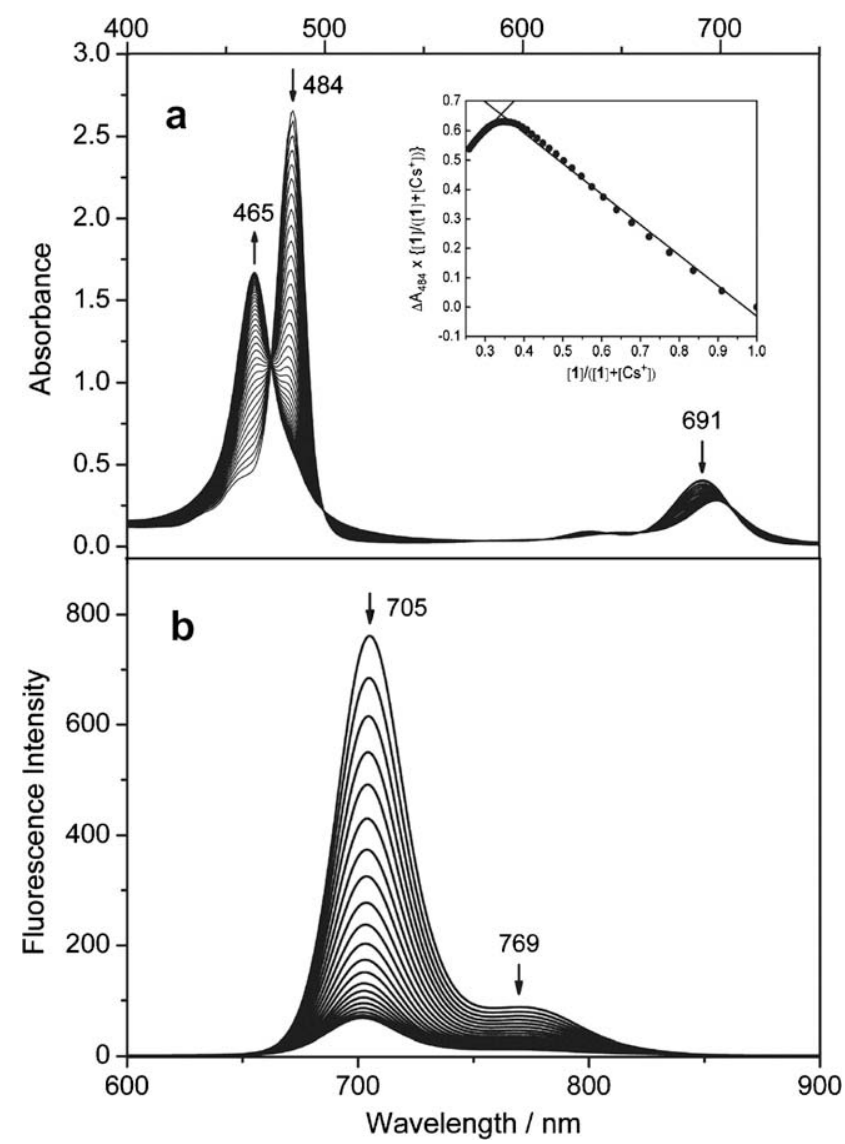

Figure 3. Spectral changes of porphyrin 1 on addition of $0-2$ equiv of $\mathrm{Cs}(\mathrm{OAc})$ in $\mathrm{CH}_{2} \mathrm{Cl}_{2} / \mathrm{CH}_{3} \mathrm{OH}$ (10:1). (a) absorption spectra, [1] $=6.0 \times 10^{-6} \mathrm{M}$; Inset: Job's plot; (b) emission spectra, $[\mathbf{1}]=2.0 \times 10^{-6} \mathrm{M} ; \lambda_{\mathrm{ex}}=473 \mathrm{~nm}$. 


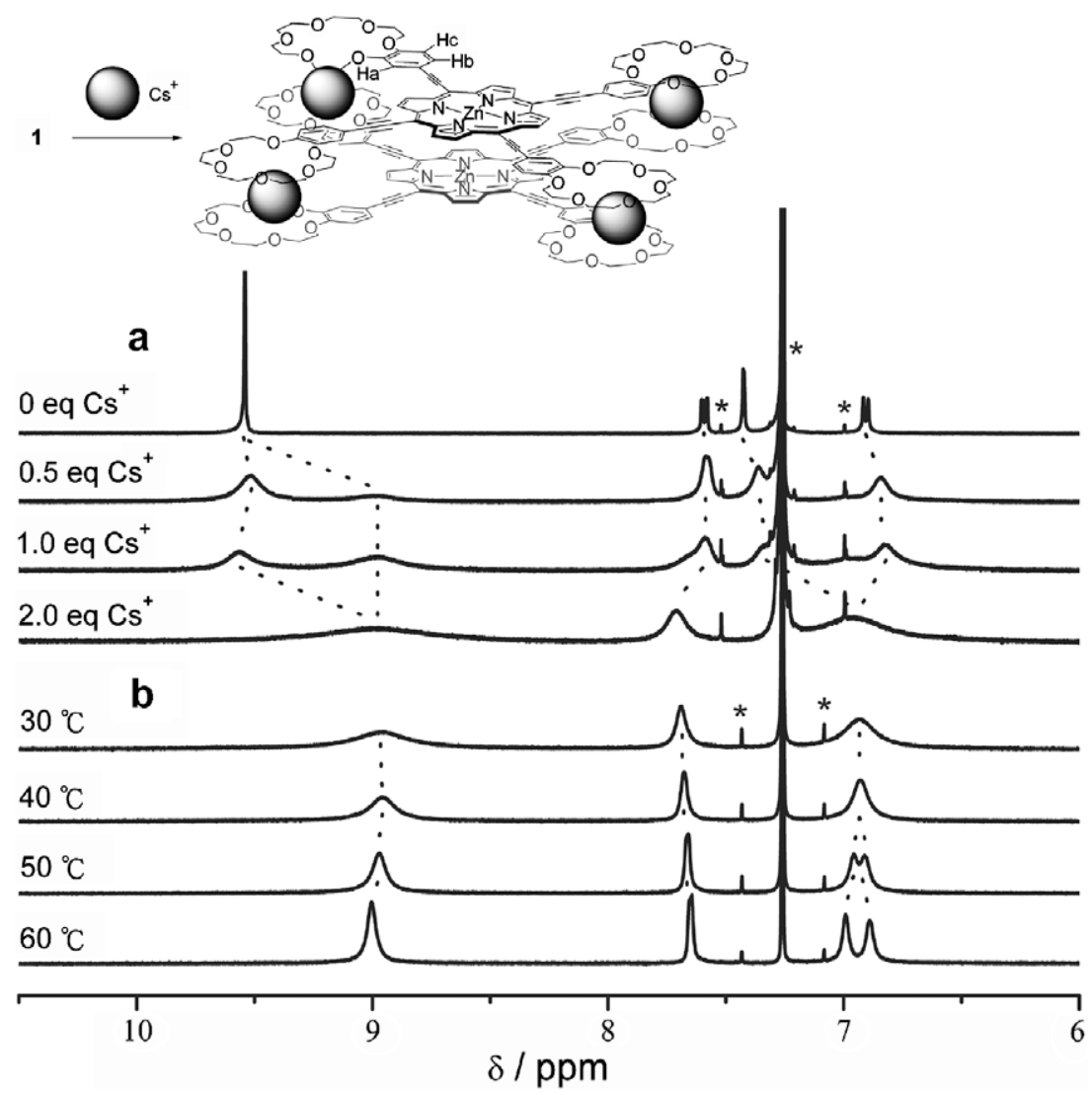

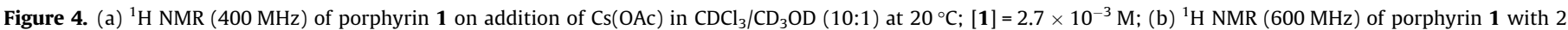
equivalents of $\mathrm{Cs}(\mathrm{OAc})$ at various temperatures. The solvent peak and sidebands are marked.

The crown ether units in $\mathbf{1}$ are more flexible for rotation than those in the phthalocyanine. It is plausible that the crown ethers in $\mathbf{1}$ can arrange to bind efficiently $\mathrm{Cs}^{+}$ions, leading to a higher stability constant. Krishnan reported that porphyrin 3 shows high selectivity to $\mathrm{K}^{+}$and the stability constant of $\left(3_{2} \mathrm{~K}_{4}\right)^{4+}$ is found to be $10^{23} \mathrm{M}^{-5}$. ${ }^{18 a}$ In a bis(5,15-benzo-15-crown-5)porphyrin system, which is favorable for $\pi-\pi$ interaction, the relative stability constant per binding site consisting of two crown ethers and one $\mathrm{K}^{+}$ ion is $10^{3}$ times larger than that in porphyrin $3{ }^{30}$ We previously reported the crystal structure of an ethynyl-linked porphyrin-triarylamine conjugate. An interporphyrin separation of $3.3 \AA$ was observed, suggesting strong $\pi-\pi$ interaction. ${ }^{31}$ The high stability constant observed for $\mathbf{1}$ is ascribed to cooperative interaction of the four crown ether binding sites and may be partly attributed to $\pi-\pi$ interaction between the porphyrin macrocycles in the dimer. The excited-state behavior of porphyrin 1 was investigated by fluorescence spectroscopy. The fluorescence spectrum of $\mathbf{1}$ exhibits emission peaks at 705 and $796 \mathrm{~nm}$. The addition of $\mathrm{Cs}^{+}$ to a solution of 1 revealed fluorescence quenching (Fig. 3b). A similar behavior was observed in the emission spectra of porphyrin 3 upon addition of metal cations. ${ }^{18 a}$

The formation of a porphyrin dimer $\left(\mathbf{1}_{2} \mathrm{Cs}_{4}\right)^{4+}$ was further investigated by ${ }^{1} \mathrm{H}$ NMR spectroscopy. As shown in Figure 4 , the NMR spectrum of porphyrin 1 exhibits signals at $9.54 \mathrm{ppm}$ for the $\beta$ hydrogens, and 7.59, 7.43, and $6.90 \mathrm{ppm}$ for the phenyl $\mathrm{H}_{\mathrm{b}}, \mathrm{H}_{\mathrm{a}}$, and $\mathrm{H}_{\mathrm{c}}$, respectively. Upon addition of $\mathrm{Cs}^{+}$ion, the $\beta$ hydrogens are shifted upfield to $9.00 \mathrm{ppm}$. This indicates that one of the macrocycle is rotated with respect to the other, thus disposing the $\beta$ hydrogens in the shielding zone. The $\mathrm{H}_{\mathrm{a}}$ signal is shifted upfield to $6.79 \mathrm{ppm}$, while the $\mathrm{H}_{\mathrm{b}}$ and $\mathrm{H}_{\mathrm{c}}$ hydrogens are shifted only slightly downfield. Considering that the crown ether units are flexible, spectral broadening at room temperature indicates that these resonances are averaged signals arising from conformational changes. At elevated temperatures, the broad signals sharpen and splitting of the signal at $6.97 \mathrm{ppm}$ is observed, because the conformational changes are fast at the NMR timescale.

Complexation of $\mathbf{1}$ was also investigated by addition of diammonium cations and the results are listed in Table 1. Figure 5a shows the UV-vis spectral changes of $\mathbf{1}$ on increasing the concentration of 1,3-propanediammonium cation. Similar to the spectral features for dimerization of $\mathbf{1}$ induced by $\mathrm{Cs}^{+}$, the Soret band is blue shifted from 484 to $464 \mathrm{~nm}$, while the Q band is slightly red shifted with decreased intensity. The blue shift of the Soret band implies

Table 1

The absorption and emission data, and stability constants of porphyrin $\mathbf{1}$ with various cations $^{\mathrm{a}}$

\begin{tabular}{lllll}
\hline Entry & Added cation & $\begin{array}{l}\text { Absorbance } \\
(\mathrm{nm})\end{array}$ & $\begin{array}{l}\text { Emission } \\
(\mathrm{nm})^{\mathrm{b}}\end{array}$ & $\begin{array}{l}\text { Stability constant } \\
(\log \beta)\end{array}$ \\
\hline 1 & $\mathbf{1}^{\mathrm{c}}$ & $484,633,691$ & 705,769 & \\
2 & $\mathrm{Cs}^{+}$ & 465,698 & 702 & $30.5 \pm 0.2$ \\
3 & $\mathrm{H}_{3} \mathrm{~N}^{+} \mathrm{C}_{2} \mathrm{H}_{4} \mathrm{~N}^{+} \mathrm{H}_{3}$ & 465,695 & 706 & $28.5 \pm 0.2$ \\
4 & $\mathrm{H}_{3} \mathrm{~N}^{+} \mathrm{C}_{3} \mathrm{H}_{6} \mathrm{~N}^{+} \mathrm{H}_{3}$ & 464,696 & 705 & $32.0 \pm 0.1$ \\
5 & $\mathrm{H}_{3} \mathrm{~N}^{+} \mathrm{C}_{4} \mathrm{H}_{8} \mathrm{~N}^{+} \mathrm{H}_{3}$ & 464,694 & 704 & $30.5 \pm 0.2$ \\
6 & $\mathrm{H}_{3} \mathrm{~N}^{+} \mathrm{C}_{5} \mathrm{H}_{10} \mathrm{~N}^{+} \mathrm{H}_{3}$ & 469,694 & 704 & $29.0 \pm 0.1$ \\
7 & $\mathrm{H}_{3} \mathrm{~N}^{+} \mathrm{C}_{6} \mathrm{H}_{12} \mathrm{~N}^{+} \mathrm{H}_{3}$ & $483,640,695$ & 709 & $30.1 \pm 0.1$ \\
8 & $\mathrm{H}_{3} \mathrm{~N}^{+} \mathrm{C}_{7} \mathrm{H}_{14} \mathrm{~N}^{+} \mathrm{H}_{3}$ & $483,640,696$ & 709 & $31.0 \pm 0.2$ \\
9 & $\mathrm{H}_{3} \mathrm{~N}^{+} \mathrm{C}_{8} \mathrm{H}_{16} \mathrm{~N}^{+} \mathrm{H}_{3}$ & $491,638,697$ & 709 & $33.7 \pm 0.3$ \\
10 & $\mathrm{H}_{3} \mathrm{~N}^{+} \mathrm{C}_{9} \mathrm{H}_{18} \mathrm{~N}^{+} \mathrm{H}_{3}$ & $491,639,696$ & 708 & $36.5 \pm 0.9$ \\
\hline
\end{tabular}

a Sovent: $\mathrm{CH}_{2} \mathrm{Cl}_{2} / \mathrm{CH}_{3} \mathrm{OH}$ (10:1).

b Excitation wavelength: $473 \mathrm{~nm}$.

c No added cations. 


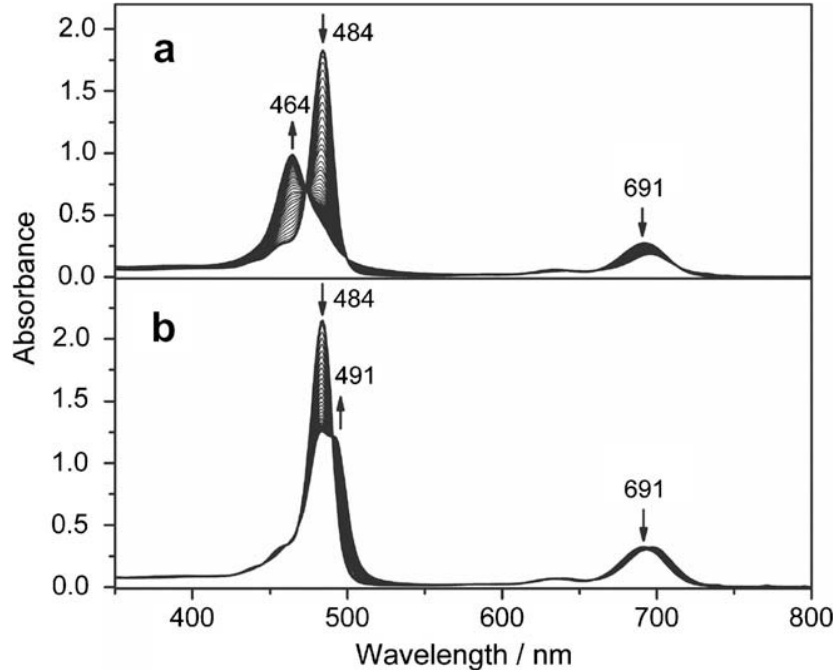

Figure 5. Spectral changes of porphyrin 1 on addition of $0-2$ equiv of (a) $\mathrm{H}_{2} \mathrm{NC}_{3} \mathrm{H}_{6} \mathrm{NH}_{2} \cdot 2 \mathrm{CF}_{3} \mathrm{CO}_{2} \mathrm{H}$ and (b) $\mathrm{H}_{2} \mathrm{NC}_{9} \mathrm{H}_{18} \mathrm{NH}_{2} \cdot 2 \mathrm{CF}_{3} \mathrm{CO}_{2} \mathrm{H}$ in $\mathrm{CH}_{2} \mathrm{Cl}_{2} / \mathrm{CH}_{3} \mathrm{OH}$ (10:1); $[\mathbf{1}]=4.0 \times 10^{-6} \mathrm{M}$

H-type stacking of the dimer. The formation of dimer was confirmed by Job's plot and the stability constant was determined to be $1.0 \times 10^{32} \mathrm{M}^{-5}$. Similarly, dimeric H-type stacking of $\mathbf{1}$ also occurs in the presence of the diammonium cations of alkylenes shorter than $-\mathrm{C}_{5} \mathrm{H}_{10^{-}}$, as evidenced by characteristic blue shift of the Soret band. Addition of 1,8-octane- or 1,9-nonanediammonium also induces dimerization of $\mathbf{1}$. However, red shifts of both Soret and $\mathrm{Q}$ bands were observed, indicating the formation of the $\mathrm{J}$ aggregated dimer (Fig. 5b). Therefore, the $\mathrm{H}$ - and J-stacking type of 1 can be controlled by complexation with the alkylenediammonium cations having an appropriate length.

In conclusion, we have synthesized a new benzo-crown ether porphyrin and its crystal structure has been obtained. Porphyrin 1 exhibits good $\mathrm{Cs}^{+}$selectivity by forming a highly stable dimeric structure. The dimerization leads to significant changes in the absorption, emission, and NMR spectral features. This porphyrin is also capable of binding alkylene diammonium cations to form a dimeric structure. It is possible that the size of the cavity between the porphyrin rings in the dimeric structure can be tuned. Molecular recognition of the dimers induced by rigid diammonium cations is now under investigation.

\section{Acknowledgments}

Science Council of Taiwan and Ministry of Education of Taiwan, under the ATU program, provided support for this project.

\section{Supplementary data}

Supplementary data associated with this article can be found, in the online version, at doi:10.1016/j.tetlet.2008.10.014.

\section{References and notes}

1. Burrell, A. K.; Officer, D. L.; Plieger, P. G.; Reid, D. C. W. Chem. Rev. 2001, 101 2751-2796.

2. Kim, D.; Osuka, A. Acc. Chem. Res. 2004, 37, 735-745.

3. Anderson, H. L. Chem. Commun. 1999, 2323-2330.

4. Holten, D.; Bocian, D. F.; Lindsey, J. S. Acc. Chem. Res. 2002, 35, 57-69.

5. Cho, H. S.; Song, H. J. K.; Min, C.-K.; Takase, M.; Aratani, N.; Cho, S.; Osuka, A.; Joo, T.; Kim, D. J. Am. Chem. Soc. 2003, 125, 5849-5860.

6. Paolesse, R.; Jaquinod, L.; Sala, F. D.; Nurco, D. J.; Prodi, L.; Montalti, M.; Natale, C. D.; D’Amico, A.; Carlo, A. D.; Lugli, P.; Smith, K. M. J. Am. Chem. Soc. 2000, 122 11295-11302.

7. Flamigni, L.; Talarico, A. M.; Chambron, J.-C.; Heitz, V.; Linke, M.; Fujita, N.; Saugvage, J.-P. Chem. Eur. J. 2004, 10, 2689-2699.

8. Drain, C. M.; Lehn, J.-M. J. Chem. Soc., Chem. Commun. 1994, 2313-2315.

9. Iengo, E.; Zangrando, E.; Alessio, E. Acc. Chem. Res. 2006, 39, 841-851.

10. Fan, J.; Whiteford, J. A.; Olenyuk, B.; Levin, M. D.; Stang, P. J.; Fleischer, E. B. J. Am. Chem. Soc. 1999, 121, 2741-2752.

11. Redman, J. E.; Feeder, N.; Teat, S. J.; Sanders, J. K. M. Inorg. Chem. 2001, 40 2486-2499.

12. Tashiro, K.; Aida, T. Chem. Soc. Rev. 2007, 36, 189-197.

13. Sessler, J. L.; Wang, B.; Harriman, A. J. Am. Chem. Soc. 1995, 117, 704-714.

14. Balaban, T. S.; Goddard, R.; Linke-Schaetzel, M.; Lehn, J.-M. J. Am. Chem. Soc. 2003, 125, 4233-4239.

15. Shi, X.; Barkigia, K. M.; Fajer, J.; Drain, C. M. J. Org. Chem. 2001, 66, 6513-6522.

16. Shirakawa, M.; Kawano, S.-i.; Fujita, N.; Sada, K.; Shinkai, S. J. Org. Chem. 2003, 68, 5037-5044.

17. Even, P.; Boitrel, B. Coord. Chem. Rev. 2006, 250, 519-541.

18. (a) Thanabal, V.; Krishnan, V. J. Am. Chem. Soc. 1982, 104, 3643-3650; (b) Thanabal, V.; Krishnan, V. Inorg. Chem. 1982, 21, 3606-3613.

19. Dürr, K.; Macpherson, B. P.; Warratz, R.; Hampel, F.; Tuczek, F.; Helmreich, M.; Jux, N.; Ivanović-Burmazović, I. J. Am. Chem. Soc. 2007, 129, 4217-4228.

20. (a) D'Souza, F.; Chitta, R.; Gadde, S.; Zandler, M. E.; McCarty, A. L.; Sandanayaka, A. S. D.; Araki, Y.; Ito, O. Chem. Eur. J. 2005, 11, 4416-4428; (b) D'Souza, F.; Chitta, R.; Sandanayaka, A. S. D.; Subbaiyan, N. K.; D'Souza, L.; Araki, Y.; Ito, O. Chem. Eur. J. 2007, 13, 8277-8284.

21. Chitta, R.; Rogers, L. M.; Wanklyn, A.; Karr, P. A.; Kahol, P. K.; Zandler, M. E; D'Souza, F. Inorg. Chem. 2004, 43, 6969-6978.

22. Marois, J.-S.; Cantin, K.; Desmarais, A.; Morin, J.-F. Org. Lett. 2008, 10, 33-36.

23. Duggan, S. A.; Fallon, G.; Langford, S. J.; Lau, V.-L.; Satchell, J. F.; Paddon-Row, M. N. J. Org. Chem. 2001, 66, 4419-4426.

24. Sun, L.; von Gersdorff, J.; Niethammer, D.; Tian, P.; Kurreck, H. Angew. Chem. Int. Ed. Engl. 1994, 33, 2318-2320.

25. Kuo, M.-C.; Li, L.-A.; Yen, W.-N.; Lo, S.-S.; Lee, C.-W.; Yeh, C.-Y. Dalton Trans. 2007, 1433-1439.

26. Crystal data for 1: $\mathrm{C}_{97.5} \mathrm{H}_{112} \mathrm{Cl}_{8} \mathrm{~N}_{4} \mathrm{O}_{26.5} \mathrm{Zn}, \quad M_{\mathrm{r}}=2112.88, \quad 0.45 \times 0.40 \times$ $0.30 \mathrm{~mm}^{3}$, triclinic, Space group $P \overline{1}, a=17.0633(2) \AA, b=18.3410(2) \AA, c=$ 19.2501(2) $\AA, \quad \alpha=63.4300(5)^{\circ}, \quad \beta=75.4837(7)^{\circ}, \quad \gamma=81.8721(6)^{\circ}, \quad V=$ $5213.23(10) \AA^{3}, Z=2, D_{\mathrm{c}}=1.346 \mathrm{~g} \mathrm{~cm}^{-3}, T=150(2) \mathrm{K}, R_{1}(I>2 \sigma(I))=0.1053$, $w R_{2}$ (all data) $=0.3219, \mathrm{GOF}=1.097 . \mathrm{CCDC}-700173$.

27. (a) Buschmann, H.-J.; Wenz, G.; Schollmeyer, E. Inorg. Chem. Commun. 2001, 4 53-56; (b) Tsuda, A.; Moriwaki, H.; Oshima, T. J. Chem. Soc., Perkin Trans. 2 1999, 1235-1240.

28. SPECTRUM Software Associate, Chapel Hill, NC, USA.

29. Sielcken, O. E.; van Tilborg, M. M.; Roks, M. F. M.; Hendriks, R.; Drenth, W.; Nolte, R. J. M. J. Am. Chem. Soc. 1987, 109, 4261-4265.

30. Shinmori, H.; Yasuda, Y.; Osuka, A. Eur. J. Org. Chem. 2002, 1197-1205.

31. Yen, W.-N.; Lo, S.-S.; Kuo, M.-C.; Mai, C.-L.; Lee, G.-H.; Peng, S.-M.; Yeh, C.-Y. Org. Lett. 2006, 8, 4239-4242. 